\title{
Investigating the long memory property of the Hungarian market pig prices by using detrended fluctuation analysis
}

\author{
Sándor Kovács ${ }^{1}$, László Huzsvai ${ }^{2}$, Péter Balogh ${ }^{3}$
}

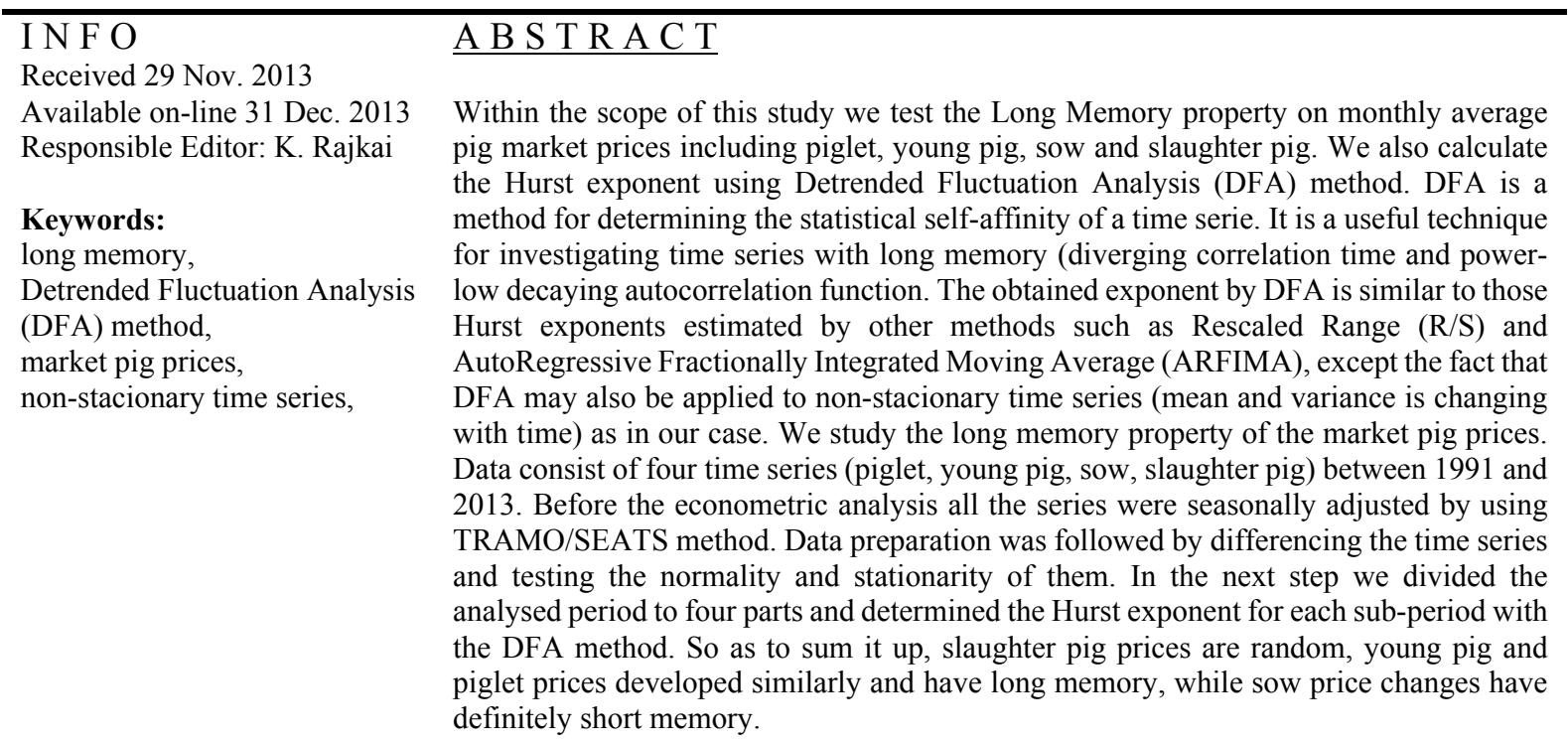

\section{Introduction}

The literature studies analysing the pig sector mentions that the emission of the sector and the prices are described by cyclical movements. Nyárs (2005) analysed the significant pig-keeping member states of the EU and the characteristic processes of the Hungarian and Polish pig sector thoroughly and stated that in the examined states the pig cycle could be revealed in different length in the tendency of buying up prices. The experts on the regulation of market processes have been examining for decades the formation price oscillations and pig cycle. The theory of the cobweb model can be found in classical economic literature. The sense of it is that the loss of market information has an effect on the behaviour of the cycle. The price of slaughter pig, crop prices and portion compared to each other have a significant effect on the decisions of pig-keepers, mainly in the case of the activity of small-scale producers. The formations of home buying-up prices are described by shorter cycles than the member states of EU having advanced pig-keeping. In the EU there are 9 year periods, while in Hungary 3 or 4-year-periods are repeated. The reason of long cycles is on the one hand the predictable market regulation and the other hand the concentrated production structure. Therefore we chose the monthly average Hungarian market prices of the period after the change of the system as a basis of our examinations.

Simply knowing that a time series has the so called long term dependence or long memory could have a strong significance when the main goal is to forecast the prices. Beside the presence of the long

\footnotetext{
${ }^{1}$ Sándor Kovács

University of Debrecen, 4032 Debrecen, Böszörményi út. 138, Hungary

kovacss@agr.unideb.hu

${ }^{2}$ László Huzsvai

University of Debrecen, 4032 Debrecen, Böszörményi út. 138, Hungary

huzsvai@agr.unideb.hu

${ }^{3}$ Péter Balogh

University of Debrecen, 4032 Debrecen, Böszörményi út. 138, Hungary

baloghp@agr.unideb.hu
} 
memory is crucial information in making business decisions and creating portfolios as well. Long memory could be measured by calculating the so called Hurst exponent. In our article we studied the Detrended Fluctuation Analysis (DFA) and calculate the Hurst exponent (Hurst, 1952) by using this method. In order to detect long-range correlations properly, it is inevitable to separate trends from the long-range fluctuations in the data. Trends are caused by external effects $-\mathrm{e}$. g. the greenhouse warming and seasonal variations for temperature records - and they are usually supposed to have a smooth and monotonous or slowly oscillating behaviour (Kantelhardt et al., 2001). It is the advantage of the DFA that it can systematically eliminate trends of different order and we can gain insight into the scaling behaviour of the natural variability in the considered time series (Kantelhardt et al., 2001). In this paper, we study systematically different orders of the DFA technique, that allow eliminating different orders of trends.

\subsection{The long memory property}

A stationary time series has the Long Memory property if the autocorrelation function decays to zero very slowly for a very long time period. The rate of decay is determined by the so called Hurst exponent $(\mathrm{H})$ according to the following expression (Beran, 1994):

$$
\text { (1) } \rho(k)=C k^{-\alpha} \text {, where } \mathrm{H}=1-\alpha / 2 \text {, }
$$

while $\mathrm{C}$ is a finite constant and $\rho(k)$ is the autocorrelation function of the time series with lag $\mathrm{k}$. According to Hurst's conclusions, if $\mathrm{H}=0.5$ than data points of the time series are independent and the series is a random walk.

If $0.5<\mathrm{H}<1$, the series indicates persistent behaviour or long memory. If there is an increase from time step $t_{i-1}$ to $t_{i}$ there will be probably be an increase from $t_{i}$ to $t_{i+1}$ (Alptekin, 2006). The same is true for decreases. A decrease will tend to follow a decrease, while an increase will tend to follow an increase.

When the Hurst exponent is positive and below 0.5 then the series is called anti-persistent. In this case, an increase will tend to be followed by a decrease or a decrease will be followed by an increase (Alptekin, 2006). This behaviour is sometimes called mean or trend reversion as a low $\mathrm{H}$ value indicates that the process could not go far from the seasonal trends and the effect of the reversions is strong.

The Hurst exponent has already been employed in many fields in Mathematics such as chaos theory and fractal analysis (Mandelbrot, 1969). As the theory of fractals has been developed, the methods for calculating the Hurst exponent have spread away widely.

\section{Data and methodology}

The agricultural prices often show irregular behaviour which refers to the nonlinear interdependency of the markets. The nonlinear interdependency in economics is not a specified concept the literature gives only some hints referring to it: the distribution of prices is in a usual way non-normal, the autocorrelations of time series even in case of long time periods are long term dependence, the time series includes non-periodical cycles and is not stationary. The long term time series involve the above mentioned characteristics so the examination of long term memory is capable of characterising the above phenomena.

Our main goal was to study the pig market prices regarding data from the past. We have already known the major deterministic factors influencing the prices but in our analysis we suppose that information on these factors is unavailable or unreliable. By this supposition we intended to give acceptable estimation on the development of the prices regarding long-memory property. The causes of trends can also be modelled by other methods (Lampe, 1998). Within the scope of our study DFA have been employed as a simple stochastic method.

\subsection{Data}

Table 1 includes the descriptive statistical indexes of four differentiated time series (piglet, young pig, sow, slaughter pig). On the basis of this it can be stated that at the whole time period the average of 
the change of pig price was the highest $2.61(\mathrm{HUF} / \mathrm{kg})$, which can be in connection with the fact that also the unit price was here the highest. The value of the median was on the contrary since at the young pigs $50 \%$ of the monthly changes were lower than $2.26 \mathrm{HUF} / \mathrm{kg}$. The standard deviation was the most significant in case of sow price changes. The minimum and maximum of changes could also be observed here (-244.99 and 201.39HUF/kg price change).

In Table 1 we included not only the characteristics of the whole time period but also the characteristics of each period. Similar to the fact observed in the whole time period the average of piglet price change was the highest except for the $3 \mathrm{rd}$ period. The value of the median fluctuated between 0 and 1 in the second period while the other periods were described by higher fluctuation. It is interesting to observe that the value of standard deviations is becoming higher and similar to the whole period while the average deviation was the highest in case of the sows in every time period. The formation of minimum values is in connection with this since in the $3 \mathrm{rd}$ period the smallest price difference between the two time points $-244.99 \mathrm{HUF} / \mathrm{kg}$ was in case of the sows. This value shows how large loss the producers suffered month after month if they were forced to sell their animals in the given period. In the case of maximum values it can be stated that except for the 4th period the highest price movement between the two months appeared at the piglet. That is the producers could reach the highest income by selling their piglets if they exploited the advantages coming from the price change. So on the basis of the Table 1 it can be stated that the differentiated price data in the various periods showed a big difference in case of the certain products.

Table 1. Descriptive statistical values of the differentiated price data.

\begin{tabular}{|c|c|c|c|c|}
\hline & & & & Unit.: HUF/kg \\
\hline Denomination & Piglet & Young pig & Sow & Slaughter pig \\
\hline \multicolumn{5}{|c|}{ Whole period } \\
\hline Mean & 2.61 & 1.76 & 1.40 & 1.36 \\
\hline Median & 0.82 & 2.26 & 0.54 & 1.29 \\
\hline Standard Deviation & 35.32 & 23.16 & 49.94 & 24.02 \\
\hline Minimum & -156.76 & -86.07 & -244.99 & -86.51 \\
\hline Maximum & 144.37 & 149.74 & 201.39 & 84.08 \\
\hline \multicolumn{5}{|c|}{ First period } \\
\hline Mean & 4.97 & 2.68 & 1.78 & 2.08 \\
\hline Median & 3.09 & 2.91 & 1.25 & 1.19 \\
\hline Standard Deviation & 10.23 & 5.93 & 8.03 & 6.66 \\
\hline Minimum & -10.34 & -14.29 & -16.08 & -8.61 \\
\hline Maximum & 32.33 & 19.35 & 19.99 & 20.96 \\
\hline \multicolumn{5}{|c|}{ Second period } \\
\hline Mean & 2.68 & 2.18 & 1.21 & 1.49 \\
\hline Median & 0.15 & 0.76 & 0.15 & 0.69 \\
\hline Standard Deviation & 30.86 & 21.08 & 42.57 & 25.30 \\
\hline Minimum & -58.76 & -51.48 & -128.23 & -86.51 \\
\hline
\end{tabular}




\begin{tabular}{|c|c|c|c|c|}
\hline Maximum & 123.02 & 65.00 & 103.62 & 77.96 \\
\hline \multicolumn{5}{|c|}{ Third period } \\
\hline Mean & -1.38 & -0.23 & 0.44 & 0.06 \\
\hline Median & -1.42 & 2.01 & -3.18 & 0.44 \\
\hline Standard Deviation & 50.22 & 24.31 & 66.01 & 25.82 \\
\hline Minimum & -156.76 & -61.72 & -244.99 & -75.65 \\
\hline Maximum & 130.68 & 39.08 & 128.75 & 55.67 \\
\hline \multicolumn{5}{|c|}{ Fourth period } \\
\hline Mean & 4.20 & 1.42 & 2.90 & 1.52 \\
\hline Median & -6.05 & 1.84 & 7.09 & 5.56 \\
\hline Standard Deviation & 50.65 & 40.95 & 82.24 & 33.04 \\
\hline Minimum & -78.86 & -86.07 & -165.30 & -71.07 \\
\hline Maximum & 144.37 & 149.74 & 201.39 & 84.08 \\
\hline
\end{tabular}

Source: Own calculation

Before examining economically the time series we must filter the season effects out. During this process we simplify time series in a way not losing important information in order to show the main processes. The time series used by us involves 21.5 whole years and it did not contained missing observations. Before the econometric analysis we adjusted the series seasonally by using TRAMO/SEATS (Golinelli-Parigi, 2008). We applied a trading day adjustment (5 day and length of month effect) and an Easter adjustment only if significant. We also detected the additive outliers, the temporary changes and the level shifts automatically. For the further investigations we used the adjusted series and Figure 1 also presents the seasonally adjusted series.

\subsection{Detrended Fluctuation Analysis (DFA)}

The basis of DFA was established by Peng et al. (1992) and was called fluctuation analysis. It was first developed for studying DNA-sequences and nucleotides (Peng et al., 1993; Peng et al., 1994). DFA is a bit different to the fluctuation analysis in such way that it removes the local trends in the series. The first application was also presented by Peng et al. (1994) and Peng et al. (1995).

The DFA procedure consists of four step. Let us suppose that we have a time series (xi) of $\mathrm{N}$ elements measured at regular intervals. In the first step we determine the cumulative sum (which is called the profile) of the time series:

$$
\text { (2) } y_{j}=\sum_{i=1}^{j} x_{i} \quad(\mathrm{j}=1, \ldots, \mathrm{N})
$$

In the second step we split the profile into l-length parts (time windows), so the maximum number of the segments is $s=\left[\frac{N}{l}\right]$, where $\mathrm{f}(\mathrm{x})=[\mathrm{x}]$ means the floor function (it gives the largest integer not greater than $\mathrm{x}$. Since N need not be multiple of the time scale 1 , in most cases a short part will remain at the end of the profile. In order to solve this problem, the same procedure is repeated starting from the other end of the profile (altogether $2 \mathrm{~s}$ segments are applied). 
In the third step we calculate the local trends denoted by $f_{k, j}^{p}$ for each segment, where $\mathrm{j}$ is the actual time point $(\mathrm{j}=1, . .1)$ in $\mathrm{k}$ segment $(\mathrm{k}=1, . ., 2 \mathrm{~s}), \mathrm{p}$ is the degree of the polynomial. Then we define the detrended time series for segment duration 1 as follows:

$$
\text { (3) } y_{l, j}=y_{j}-f_{k, j}^{p}(\mathrm{j}=1, \ldots, \mathrm{N})
$$

Given the order of the fitted polynomial the method can be called DFA-1 (first order polynomials are used) or DFA-2 (second order polynomials are used).

In the fourth step, we calculate the fluctuation for each segment $\mathrm{k}$ as the variance of $y_{l}(j)$ (Peng et al., 1993; Peng et al., 1994; (J. W. Kantelhardt et al., 2001):

$$
\text { (4) } F_{l, k}^{2}=\frac{1}{l} \sum_{j=1}^{l} y_{l,[(k-1) l+j]}^{2}
$$

Finally, we average over all segments and take square root to obtain the DFA fluctuation (where $\mathrm{p}$ is the order of the fitted polynomials) as follows:

$$
\text { (5) } F_{p, l}=\sqrt{\frac{1}{2 s} \sum_{k=1}^{2 s} F_{l, k}^{2}}
$$

We are interested in 1-dependence of $F p(l)$. In case of long range dependence we suppose that is the power of 1 with the DFA-p exponent $\delta / F_{p}(l) \approx l^{\delta} /$. Short-range dependent time series have $\delta=0.5$, long-range dependent series are characterized by a $\delta>0.5$, while anti-persistent series have $\delta<0.5$ (Koscielny-Bunde et al., 1998; Talkner-Weber, 2000; Király, 2005).

\section{Results}

The observed prices were as follows the average price of piglet, young pig, sow, slaughter pig in the animal markets and fairs. To the empirical analysis there were in all the four categories 270 observations that is monthly average market prices observed between January 1991. and June 2013. at our disposal.

\subsection{The monthly formation of seasonally adjusted market pig price data between January 1991. and June 2013.}

Figure 1 shows that during the period after the regime change the basic trend in pig market prices is slightly increasing. According to Bakucs - Fertő (2005) the market is still basically the buyer's market which affects the development of the prices apart from the seasonal and cyclical effects. In each case the average prices have changed according to a 3-years cycle which turned to a 4-years cycle after joining to the EU. Price developments show a large fluctuation over the 20 years so we had to divide the whole period to 4 sub periods from a professional standpoint and analyse the four series even in these sub periods. The first part contains data from 1991 to 1994 as prices were almost continuously increasing without any cyclical affect. The second part involves data from 1995 to 2004. In this period there had been a large cyclical effect which caused a 3-years movement in the prices. It is also observable that slaughter pig prices and sow prices developed the same way.

The third period covers the first stage after the EU joining in which the prices had been decreased or stagnated. There had been a dramatic decrease in case of the pig and piglet prices. The final sub-period as a second stage after the EU joining lasts from July in 2008 to June in 2013. In this stage we can observe a steady increase in pig and piglet market prices, while slaughter pig prices increased in a modest way (Figure 1) and sow prices follow a random movement.

\subsection{Economical analysis of the data}

Long memory is not a clearly specified concept in the financial theory authors only give hints to the signs which could indicate it. For example the prices are usually distributed normally, the autocorrelation 
function decays zero very slowly even for a very large period, the series has non periodic cycles and not stationary (Taylor, 1986). According to these symptoms we would further test the seasonally adjusted time series in order to find more evidence of long memory.

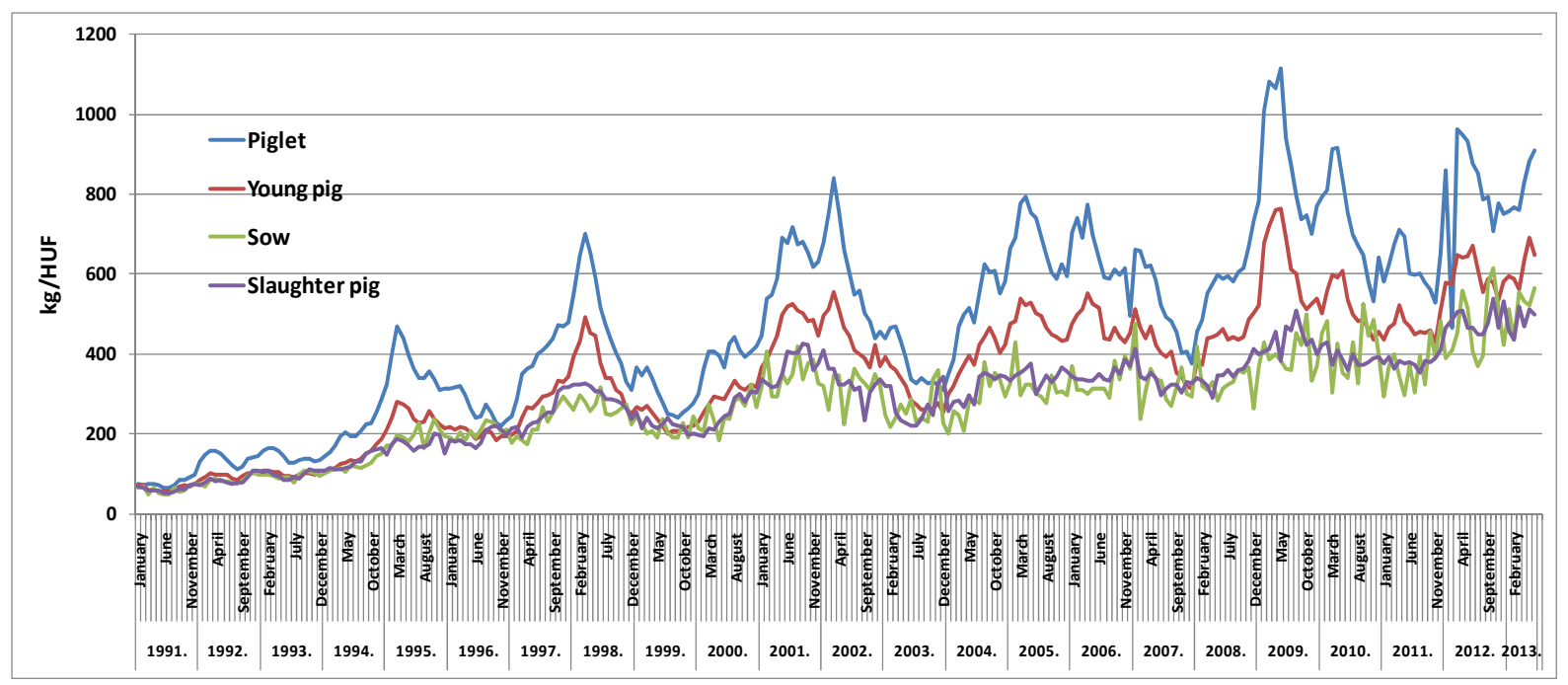

Remark: The seasonal adjustment was used by the TRAMO/SEATS-program.

Source: Magyar Statisztikai Évkönyv [1991 - 2006] and KSH stAdat táblák (2013)

Figure 1. Seasonally adjusted monthly average pig prices /1991- 2013/ (in HUF/kg).

Table 2. Normality test results of the seasonal adjusted time series.

\begin{tabular}{|l|c|c|c|c|}
\hline \multicolumn{1}{|c|}{ Tests } & Piglet & Young pig & Sow & Slaughter pig \\
\hline Doornik-Hansen* & 7.985 & 12.155 & 9.168 & 15.227 \\
& $(0.018)$ & $(0.002)$ & $(0.010)$ & $(0.000)$ \\
\hline Shapiro-Wilk & 0.969 & 0.965 & 0.969 & 0.959 \\
& $(0.000)$ & $(0.000)$ & $(0.000)$ & $(0.000)$ \\
\hline Lilliefors** & 0.062 & 0.075 & 0.085 & 0.114 \\
& $(0.030)$ & $(0.000)$ & $(0.000)$ & $(0.000)$ \\
\hline Jarque-Bera & 8.26 & 8.799 & 6.296 & 9.229 \\
& $(0.016)$ & $(0.012)$ & $(0.043)$ & $(0.010)$ \\
\hline
\end{tabular}

Remark: Econometric Software GRETL was used to test normality, significances are in parenthesis *Doornik and Hansen (2008); ** Lilliefors (1967)

The normality and stationarity of the series were tested as well as the decay of their autocorrelation function. Long memory processes exhibit non-normality and non-stationarity, their autocorrelation function decays to zero very slowly. Normality test results can be seen in Table 2 .

The null hypothesis of the normality tests is that data is normally distributed. All the tests proved significant at 5\% significance level so we can reject the hypothesis of normality in each case. 
Table 3. Stationarity test results of the seasonal adjusted time series by ADF-test.

\begin{tabular}{lcccc}
\hline Model & Piglet & Young pig & Sow & Slaughter pig \\
Constant & -2.39509 & -2.134 & -1.587 & -1.547 \\
& $(0.1431)$ & $(0.231)$ & $(0.488)$ & $(0.509)$ \\
Constant and trend & -4.57618 & -4.446 & -3.274 & -2.962 \\
& $(0.001)$ & $(0.001)$ & $(0.071)$ & $(0.143)$ \\
Differentiated series & -8.19323 & -7.549 & -10.917 & -7.544 \\
& $(0.000)$ & $(0.000)$ & $(0.000)$ & $(0.000)$
\end{tabular}

Remark: Econometric Software GRETL was used to test normality, we employed the Augmented-Dickey-Fuller test, significances are in parenthesis

The null hypothesis of the ADF test is that the time series has a unit root as the time series is nonstationary. The test proves non-stationarity in all cases as the null hypothesis can not be rejected at $5 \%$ significance level (Table 3). Pig and piglet market prices are trend stationary, the other series are not. On the other hand, the differenced series are all stationary, so it was reasonable to difference the seasonally adjusted series and apply the Hurst exponent estimations to them.

Before we turn to the results of the estimations one thing must be strongly emphasized. In case $\mathrm{H}=0.5$ the original data follows a random movement as it is non-stationary. The differenced series (price change) is stationary so can not follow a random movement.

Table 4. DFA-2* estimated Hurst exponents.

\begin{tabular}{ccccc}
\hline Sub period & Piglet & Young pig & Sow & Slaughter pig \\
1. & 0.839 & 0.765 & 0.459 & 0.824 \\
2. & 0.852 & 0.785 & 0.223 & 0.477 \\
3. & 0.397 & 0.555 & 0.256 & 0.497 \\
4. & 0.588 & 0.686 & 0.274 & 0.525
\end{tabular}

$\begin{array}{llll}\text { Whole period } & 0.750 & 0.709 & 0.162\end{array}$

*Remarks: Estimations were made by the DFA Software with $p=2$, quadratic polynomials were used for detrending the series (PhysioNet [2010]).

Average sow market price changes have short memory in all sub-periods and in the whole period (Table 4). Slaughter pig price changes did not have long memory except in the first sub-period. The Hurst exponents of the pig and piglet price changes are very similar to each other, except the third subperiod in all other sub-periods and in the whole period they had long memory. The slaughter pig price changes had short memory in the whole period, and the original prices show random movement in all sub-period except the first one. These statements are in a great balance with Figure 1.

\section{Conclusions}

In order to detect long-range correlations properly, it is inevitable to separate trends from the longrange fluctuations in the data. The major advantage of the DFA is to systematically eliminate trends of different order and to gain better insight into the scaling behavior of the variability in a given time series.

On the basis of our analysis it can be stated that the DFA method applied for the examination of long term memory exactly proved the characteristics described on the certain periods of seasonally adjusted time series. During the examination of the change of the sow prices the DFA-2 showed short-term memory in price changes. The explanation for this can be that the price of sows appearing on the market 
is partly independent of the breeding animal prices of the earlier periods. Piglet and young pig price changes have long-memory across the whole time period except after the joining to the EU (the 3rd period). The changes of slaughter pig prices between 1991-1994 (first period) turned to be having a long term memory. The data of the original time series in the 2-4th periods are similar to random walking and the price changes in total have short term memory on the basis of the DFA-2 method.

So as to sum it up, slaughter pig prices are random, young pig and piglet prices developed similarly and have long memory, while sow price changes have definitely short memory, which means that a decrease will probably be followed by a decrease in the long run.

Information on the long-memory dynamics will support the decision making process of different economic operators as producers, traders, publicauthorities. Sales revenues of stock farms fluctuate due to the short memory of the prices but it is still calculable. On the other hand, the acquisition costs of slaughter-pig farms are much more stable because of the presence of the long-memory in the prices. As the slaughter pig prices are almost random, the sales revenues of slaughter-pig farms fluctuate randomly.

\section{References}

Ahti, V. [2009]: Forecasting Commodity Prices with Nonlinear Models, Discussion Paper No. 268, University of Helsinki, Helsinki, http://ethesis.helsinki.fi/julkaisut/eri/hecer/disc/268/forecast.pdf

Alptekin, N. [2006]: Long Memory Analysis of USD/TRL Exchange Rate International Journal of Social Sciences 1(2):111-116

Application to daily temperatures. Physical Review E, 62:150-160.

Bakucs, L. Z. - Fertő, I. [2005]: Marketing Margins and Price Transmission on the Hungarian Pork Meat Market. Agribusiness. 21(2):273-286.

Beran, J. [1994]: Statistics for Long-Memory Processes. Chapman and Hall Publishing Inc. New York.

Booth, G.G. - Kaen, F.R. - Koveos, P.E. [1982]: R/S Analyses of Foreign Exchange Rates under Two International Monetary Regimes. Journal of Monetary Economics. 10:407-415.

Cheung, Y.W. - Lai, K.S. [1993]: Do Gold Market Returns Have Long Memory? The Financial Review. 28:181202.

Chow, K.V. - Denning, K.C. - Ferris, S. - Noronha, G. [1995]: Long-Term and Short-Term Price Memory in the Stock Market. Economic Letters. 49:287-293.

Doornik, J.A. - Hansen, H. [2008]: An Omnibus Test for Univariate and Multivariate Normality. Oxford Bulletin of Economics and Statistics. 70: 927-939.

Eisler, Z. [2007]: Fluctuation Phenomena on the stock market, PhD. Thesis, Budapest University of Technology and Economics, Budapest.

Erfani, A. - Samimi, A. J. [2009]: Long memory forecasting of stock price index using a fractionally differenced Arma model, Journal of Applied Sciences Research, 5(10):1721-1731.

Fang, H.K. - Lai, S. - Lai, M. [1994]: Fractal Structure in Currency Futures Price Dynamics. The Journal of Futures Markets. 14(2):169-181.

Golinelli, R. - Parigi, G. [2008]: Real-Time Squared: A Real-time Data set for Real-Time GDP Forecasting. International Journal of Forecasting. 24(3):368-385.

Granger, C.W.J. - Joyeux, R. [1980]: An Introduction to Long-Memory Time Series Models and Fractal Differencing. Journal of Time Series Analysis. 1:15-29.

Helms, B.P. - Kaen, F.R. - Rosenman, R.E. [1984]: Memory in Commodity Futures Contracts. The Journal of Futures Markets. 10:559-567.

Hosking, J.R.M. [1981]: Fractal Differencing. Biometrika. 68:165-176.

Hurst, H. E. [1951]: Long-term storage capacity of reservoirs. Trans. Am. Soc. Civil Engrs., 116:770-808

Hurst, H.E. [1952]: The Nile. Constable and Company. England.

Kantelhardt, J. W. - E. Koscielny-Bunde, H. A. Rego, S. Havlin, A. Bunde [2001]: Detecting long-range correlations with Detrended Fluctuation Analysis. Physica A 295, 441-454. 
Kohzadi, N. -Boyd, M. S. - Kermanshahi, B. - Kaastra, I. [1996]: A comparison of artificial neural network and time series models for forecasting commodity prices, Neurocomputing, 10(2):169-181

Korkmaz, T. - Cevik, E.I. - Özatac, N. [2009]: Testing for Long Memory in ISE Using ARFIMA-FIGARCH Model and Structural Break Test, International Research Journal of Finance and Economics, 26:186-191

Koscielny-Bunde, E. - Bunde, A. - Havlin, S. - Roman, H. E. - Goldreich, Y. - Schellnhuber, H. J. [1998]: Indication of an universal persistence law governing atmospheric variability. Physical Review Letters, 81:729732.

Ksh Stadat-Táblák [2010]: A fontosabb élö állatok átlagára az állatpiacokon és -vásárokon. Malac, süldő, anyakoca, vágósertés átlagára az állatpiacokon és -vásárokon 2006-tól 2010-ig.

http://portal.ksh.hu/pls/ksh/docs/hun/xstadat/xstadat_evkozi/e_qsma006b.html

Lampe, von M. [1998]: The World Agricultural Trade Simulation System WATSIM: AN Overview. http://www.researchgate.net/publication/23516428_The_World_Agricultural_Trade_Simulation_System_WATS IM_An_Overview

Lilliefors, H. [1967]: On the Kolmogorov-Smirnov test for normality with mean and variance unknown. Journal of the American Statistical Association. 62:399-402.

Magyar Statisztikai Évkönyv [1991 - 2006]: KSH. Budapest.

Mandelbrot, B. [1969]: The Robustness of the Rescaled Range R/S in the Measurement of Noncyclic Long-Run Statistical Dependence. Water Resources Research. 5:967-988.

Nyárs L. [2005]: A magyar sertéshústermelés gazdasági környezetének vizsgálata. PhD-értekezés. Gödöllő. (Working paper.)

Peng, C. K. - Havlin, S. - Stanley, H. E. - Goldberger, A. L. [1995]: Quantification of scaling exponents and crossover phenomena in nonstationary heartbeat time series Chaos, 5:82-87.

Peng, C.K - Buldyrev S.V. - Havlin, S. - Simons, M. - Stanley, H.E. - Goldberger A.L. [1994]: Mosaic organization of DNA nucleotides, Physical Review E, 49:1685-1689.

Peng, C.K. - Buldyrev, S. V. - Goldberger, A. L. - Havlin, S. - Sciortino, F. - Simons, M. - Stanley, H. E. [1992]: Long-range correlations in nucleotide sequences. Nature, 356:168-170.

Peng, C.K. - Buldyrev, S. V. - Goldberger, A. L. - Havlin, S. - Simons, M. - Stanley, H. E. [1993]: Finite-size effects on long-range correlations: Implications for analyzing DNA sequences. Physical Review E, 47:37303733 .

Physionet Statistical Softver [2010]: Detrended Fluctuation Analysis, http://www.physionet.org/physiotools/dfa/

Power, G.J. - Turvey, C. G. [2010]: Long-range dependence in the volatility of commodity futures prices:

Wavelet-based evidence, Physica A: Statistical Mechanics and its Applications 389(1):79-90

Ramirez, J.A. - Alvarez, J. - Rodriguez, E. [2008]: Short-term predictability of crude oil markets: A detrended fluctuation analysis approach, Energy Economics, 30(5):2645- 2656.

Sewell, M. [2010]: Rescaled range analysis software, http://www.long-memory.com/

Shahwan, T. - Odening, M. [2007]: Forecasting Agricultural Commodity Prices using Hybrid Neural Networks, In: Computational Intelligence in Economics and Finance (Eds: Shu-Heng Chen, Paul P. Wang and Tzu-Wen Kuo), Springer, Berlin, 63-74.

Talkner, P. - Weber, R. O. [2000]: Power spectrum and detrended fluctuation analysis:

Taylor, S. [1986]: Modelling Financial Time Series. John Wiley \& Sons, Inc. New York.

Telcs A. [2009]: Igazságos játékok a pénzfeldobástól a tőzsdéig. BME, Budapest, 157-158 http://www.szit.bme.hu/ telcs/pfj.pdf

Tomek, W.G. [1994]: Dependence in Commodity Prices: A Commen. The Journal of Futures Markets. 14:103109.

Tsypalkov, A. [2004]: Matrixer econometric program, http://matrixer.narod.ru/

Wei, A. - Leuthold, R. M. [2000]: Agricultural Futures Prices and Long Memory Processes, Working paper No. 00.04, Social Science Research Network http://papers.ssrn.com/sol3/papers.cfm?abstract_id=229795 